\section{form $A \wedge A D E N$ NiSK}

Vol I4, No 2 (202I) https://doi.org/10.7577/formakademisk.4180

Riikka Latva-Somppi

Doctoral student, Master of Arts

Aalto University

School of Arts, Design and Architecture, Department of Design riikka.latva-somppi@aalto.fi

Maarit Mäkelä

Associate Professor, Doctor of Arts

Aalto University

School of Arts Design and Architecture, Department of Design maarit.makela@aalto.fi

Kristina Lindström

Senior lecturer, PhD

Malmö University

Faculty of Culture and Society, School of Arts and Communication kristina.lindstrom@mau.se

Åsa Ståhl

Senior lecturer, PhD

Linnaeus University

Faculty of Arts and Humanities, Department of Design asa.stahl@Inu.se

\title{
Entangled Materialities
}

\section{Caring for soil communities at glass industry sites}

\begin{abstract}
This paper discusses craft and design practices through their impact on the environment. We consider how to act concerning the consequences of the craft and design industry. Also, we reflect on the agency of our field of practice in changing how we perceive the environment. We present three case studies of the European glass industry sites in Sweden, Italy and Finland, where we study contamination of the soil with participatory, speculative and craft methods. Through these cases, we reflect on our role in soil communities and ask how we may act in them with responsibility, hope and care. We conclude by proposing to act locally, to share our practices and make them visible, expanding our situated, personal skills and knowledge towards the political.
\end{abstract}

Keywords:

Soil, Craft and Design, Aftermath, Glass industry, Care. 


\section{INTRODUCTION}

Design is traditionally regarded as the practice of making (new things). A designerly impetus is to solve how things ought to be (Simon, 1969). In craft, a specific area of design, making extends to areas of conservation and restoration. Design researcher Ramia Mazé (2013) explains that design involves synthesizing knowledge from across sciences to solve complex technical and social problems. The field of design has previously mainly been targeted at creating desires for new consumer products, thus consuming natural resources such as energy, water and earth metals. Mazé argues that design is now also taking a central role in the sustainable development discourse by engaging critically and politically in the issues of resource consumption. In search of "how things ought to be", the very idea of design is rethought and reformulated to include design practices similar to art, pedagogy or activism. In doing so, she continues, design extends to, for example, feminist and environmental theories which are explicitly grounded in exploring how things could be otherwise (Mazé, 2013, pp. 83-110).

Design processes and systems make ideas, objects and spaces become real and thus have a great capacity to affect how we live in the world (Fletcher et al., 2019, p. 9). Design researcher Louise St. Pierre (2019) understands design as a systematic activity that shapes the world through artefacts, interactions and communication materials (p. 92). She states that the design field, including the area of craft, therefore has a tremendous impact on nature and how nature is perceived.

In the storyline of what is now being termed the Anthropocene, humanity has now entered in its third phase (Steffen et al., 2007, pp. 618-619), characterised by a growing awareness of the consequences that humans have had on the geological environment. It has become evident that nonhuman forces react to the impact of humans and guide the ways in which we live and practise. We do not argue for or against (see Malm \& Hornborg, 2014; Haraway, 2016) the concept of the Anthropocene, but instead acknowledge what design researchers such as Akama et al. (2020) have proposed that more critical, more inclusive - and including also more-than-human entities - craft and design practices are needed in the concurrent planetary situation: Being aware of how worlds and futures are formed in coexistence with multiple others, human and non-human, requires rethinking with ethical, political and onto-epistemological interrogations. Architect and researcher Lydia Kallipoliti (2018) invites designers to rethink the idea of ecology - living organisms and their interrelations in their biotic and abiotic habitat - as a recirculatory understanding of the world. She suggests making room for design practices that decentralise humans and see the world of ideas, information and matter as flows rather than an accumulation of objects (pp. 42-43).

In this study, we use our situated knowledge (Haraway, 1991; Akama et al., 2020, p. 9), to examine how we can use our skill as design and craft practitioners in a response-able (Haraway, 2016) way to act in the aftermath of the production of design objects. We will discuss three cases which are all place-based and context-dependent (St. Pierre 2019, pp. 104-105) as they are situated in specific sites of ecological disruption, that is in places where the glass industry has contaminated soil in Sweden, Italy and Finland. We do not propose practical or technical resolutions to the environmental problems, but examine, as explained by Akama et al. (2018) how we may participate in the change-making instead through intervention and openness (p. 3). We do so by looking back into history to trace how our professional field has participated in changing the materiality of the environment. We also dwell in the troubling present (Haraway, 2016) and reconsider how we use our practice with humility to understand ecological relationality in the geological environments in question. By bringing these situated cases together, we also hope to articulate partial connections that link these sites (Strathern, 2004).

We conclude, based on the three case studies, by proposing three ways of acting to shift craft and design's agency towards the ecological: First, going to the sites in question and exploring them attentively, including the personal and subjective experiences; second, inviting others to share with us the immersive practices and the narratives around soil; third, making the abovementioned acts visible, thus taking a step towards the political.

We, the authors of this article, are craft and design practitioners who also situate our practices in the field of research. Riikka Latva-Somppi has achieved her skills in the craft and design field by working in the area of glass art, and Maarit Mäkelä has gained her experience as a practicing ceramic artist. Kristina Lindström and Åsa Ståhl, on the other hand, work at the intersection of participatory and 
speculative design. ${ }^{1}$ We four are also the same persons who have planned, conducted and carried out the three case studies.

\section{THE AFTERMATH OF THE GLASS INDUSTRY: THREE CASES}

Glassmaking is a traditional craft, requiring a specific skill often obtained only through years of experience. The glass making skill has been passed down in factories from masters to skilled manual workers lower in the hierarchy of production and from them to apprentices. In particular, the glassblowing craft has often been kept in families (Metsänkylä \& Suutari, 1992, p. 9). As with many industries, entire villages and glass communities were formed around glass factories. Thus, the sites of glass production often have long histories, allowing a slow accumulation of heavy metals in the environment. As such, the soil at these sites can be regarded as a geological archive (Denizen, 2013, p. 42) of the glass industry (Figure 1).

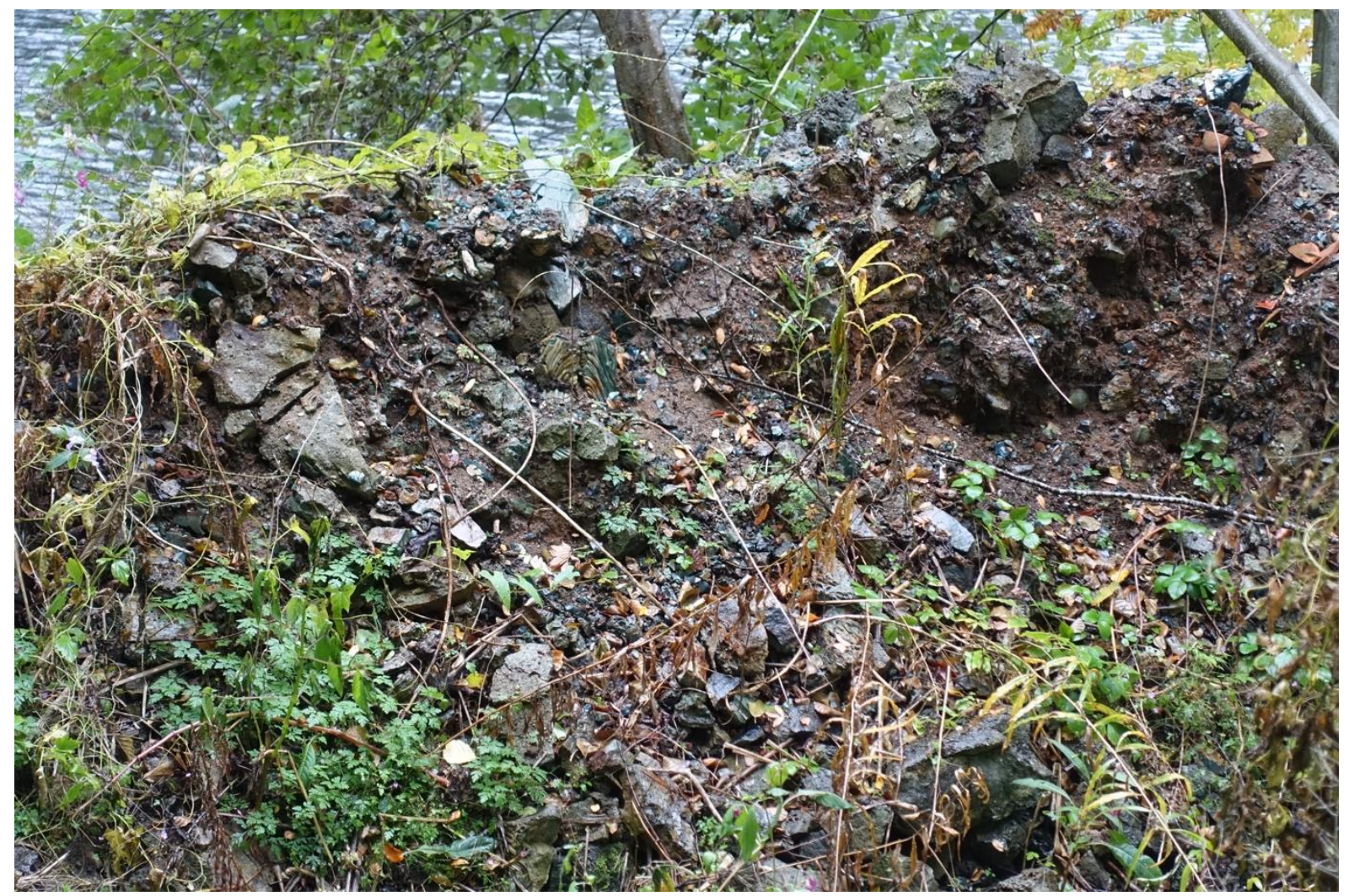

FIGURE 1. Soil in the Kingdom of Crystal, Sweden. Photo: Louize Mazet.

Feminist science and technology studies scholar Maria Puig de la Bellacasa (2015) points out that what we think soil is affects the way we care for it (p. 2). Deviating from the idea of soil only as a commodity for making design objects, we regard, through the cases presented in this paper, soils as living environments of soil communities (Lindström \& Ståhl, 2019, Puig de la Bellacasa, 2015). Importantly, as Puig de la Bellacasa acknowledges, soil communities do not only include micro-organisms, plants and worms, but also humans - with obligations as well as vulnerabilities. This concept can be traced to philosopher and conservationist Aldo Leopold's (1949/2020) famous "land ethic" in understanding that the role of humans is not that of a conqueror or exploiter, but that we are citizens of land communities, able to care for and respect our fellow-members of the community as well as the community itself ( $p$. 192). Puig de la Bellacasa (2015) states that soil care and soil ontologies are entangled: Changing how we care for soil also challenges the way we think of it (p. 2). Caring from the perspective of maintenance or caring with a progressivist and productionist ethos create different relationalities (p. 8). 
We will discuss three case studies that draw on and are in dialogue with feminist technoscience and environmental sciences. Two main design practices are used: on the one hand, speculative and participatory approaches and, on the other hand, craft practice.

In the first case, participants were invited to engage with the speculative method of asking plants for help to clean polluted soil in the Kingdom of Crystal, southern Sweden. This was a way of thinking and acting together with the residents in an area where the glass industry has contributed jobs, iconic design and a bustling community - but also a poisonous legacy (Lindström \& Ståhl, 2019; 2020). The focus was on gaining more awareness on how to act concerning the consequences of the design industry and how more-than-humans participate in unmaking damage that humans cannot repair alone (Akama et al., 2020, p. 2).

In the second case, craft practitioners studied the local environment of the Venice Lagoon area. They used soil contamination research methods, such as gathering and analysing soil and sediment samples in tandem with ceramic art practice (Latva-Somppi \& Mäkelä, 2020; Latva-Somppi et al., 2020). The soil was analysed for heavy metals and processed into ceramic material. The project aimed to reflect on how humans become with their environment and how the materiality of soil changes through human actions.

The two abovementioned practices - speculative and participatory design practice and craft practice - merge in the third case, which is presented as an ongoing project located in the Glass Village of Nuutajärvi in Finland. There, an invitation based on experiences and insights gained from the first case study was passed on to the craft practitioners of the second case to engage with local sites of the glass industry in their own country, Finland. In response to the invitation, the soil and its contaminants are studied with speculative design methods, such as rethinking the concept of mining metals with the help of plants aiming to revisit aiming to revisit the old craft knowledge of using plant ash to replace minerals and metals in ceramic glazing. The public can follow the practical research taking place in an exhibition space surrounded by a display which also includes iconic glass design objects made in the former Nuutajärvi glass factory. In the following, we will discuss the three cases in more detail.

\section{The case of Kingdom of Crystal: Un/making soil communities}

The first case, Un/making Soil Communities, asks how we should engage with the consequences of design and whom to include and how (Lindström \& Ståhl, 2020). The project took place in Småland in Southern Sweden in an area which is called the Kingdom of Crystal for its extensive glass production, dating back to 1742. Especially in the 20th century, Swedish glass designers and artists working for factories in this area boosted the reputation of Sweden's desired avant-garde glassware; however, the success of the industry has left its mark in the soil. High amounts of metals such as arsenic, cadmium, lead and zinc have been detected in the open glass dumps where factory wastes have been deposited (Mutafela et al., 2019). Significant concentrations of these harmful metals have been found even in the soil of public and residential gardens in the area (Helmfrid, 2014). Elevated levels of carcinogenic arsenic in garden vegetables grown in the area indicate its presence in the local soil food webs (Uddh-Söderberg et al., 2015).

The polluted soil in the Kingdom of Crystal is a well-known fact, but ideas on how to care for it vary (Lindström \& Ståhl 2020, p. 16). The main idea of soil remediation has been to remove the polluted layers and replace them with clean soil (J. Reinikainen, personal communication, August 20, 2019). In some cases, this may create more harm for the environment as removing and placing the contaminated soil does not solve the problem, only changes its location. Also, experimental concepts such as glass mining and phytoremediation, the ability of specific plants to remediate soil, have been discussed as one solution to the local problem (Hogland et al., 2019). 
To further speculate on the un/making of the polluted soil with plants, the designers invited the residents of the area to think together on how they could care for the environment (Lindström \& Ståhl, 2020, p. 16) (Figure 2). They crafted invitations for the residents asking to think of soil in a specific place that they thought needed care. The participatory workshops were made in new iterations along the way. First, designers and residents visited the sites picked by the residents. Such sites were locations marked on official maps indicating areas of polluted soil, as well as resident gardens and a rail track area turned into a recreational zone. During these walks, the thoughts shared were not primarily speculations on the future, but rather reflecting on the past practices and living in the area. The proposal to care for these places with plants sparked curiosity and interest, but also worry. For example, the white lupin was recognised as an invasive species, and since all of the suggested plants were edible there were worries about what would happen if they were eaten by mistake. Images, field notes and soil samples were shown as a work-in-progress in the exhibition Multispecies Storytelling at Växjö Art Gallery at the beginning of 2019 to make visible the need for care and to invite engagement rather than simply exhibit a solution (Figure 3).
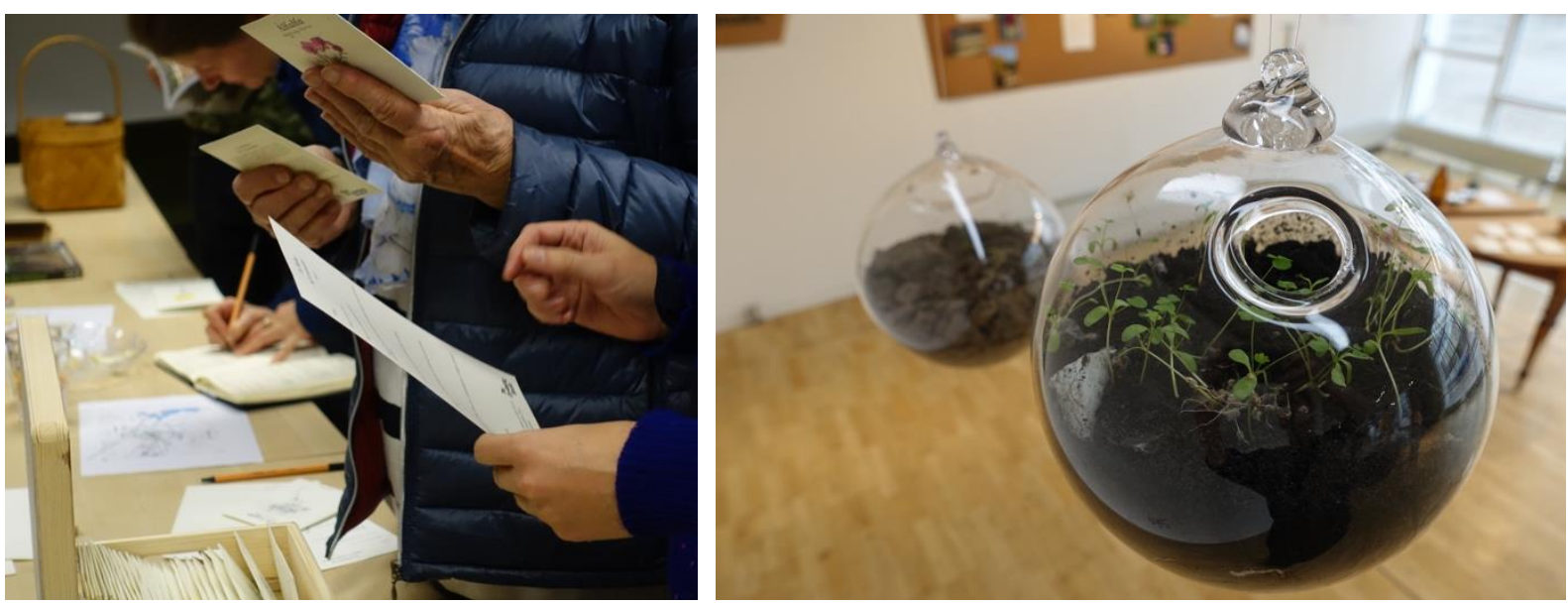

FIGURE 2 AND 3. The residents getting to know plants that accumulate metals (Figure 2). Photo: Louize Mazet. The soil and seeds were placed in glass spheres that were hand-blown in a contemporary local glassworks (Figure 3). Photo: Kristina Lindström.

To respond to the uncertainties that emerged during the site visits and the desire to know more about the soil, the designers set up two soil scanning workshops in collaboration with two doctoral students of environmental science. One of the workshops was set in the exhibition space. The other took place on location during a cleaning day that was organised by a local community. During both workshops, residents were invited to collect and bring soil samples (Figure 4) from various sites of interest. The environmental scientists then scanned the soil samples, using X-ray fluorescence to detect metals in the soil. Then, seeds of plants which would potentially phytoremediate the polluted soil were distributed (Figure 5). 

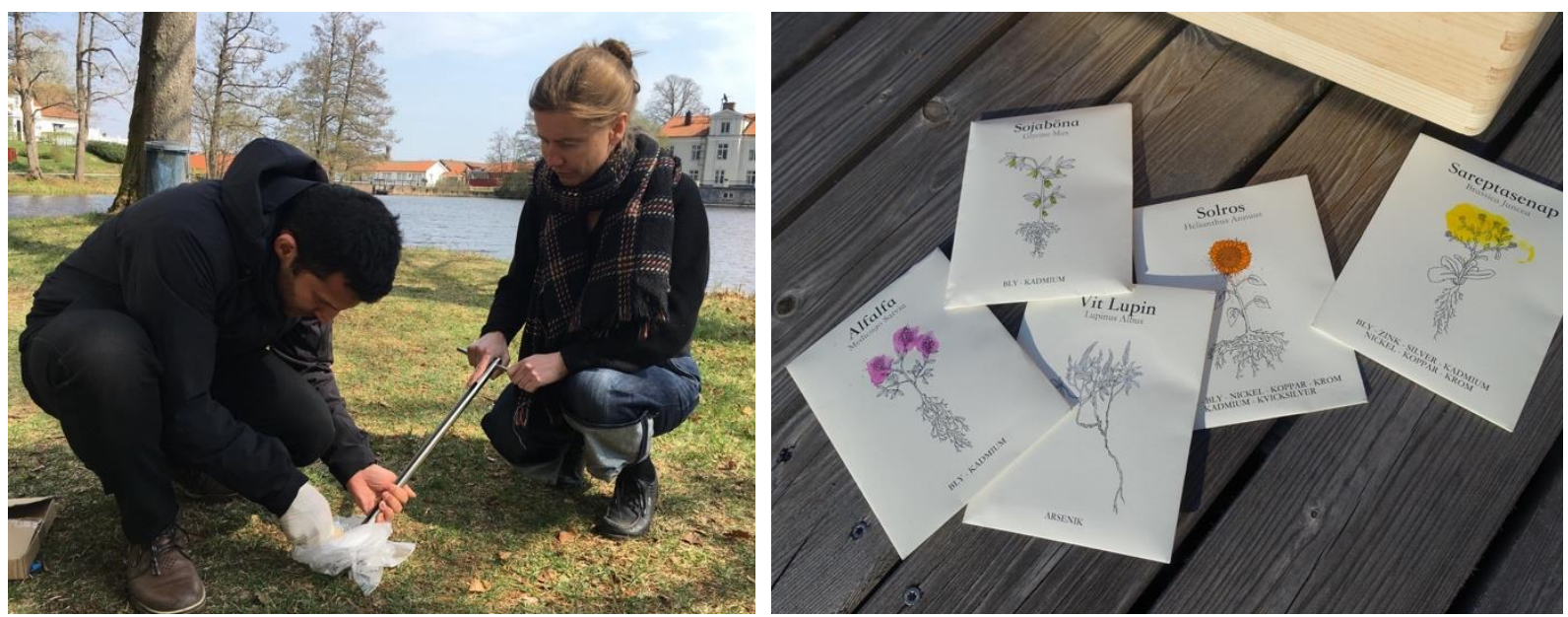

FIGURE 4 AND 5. Taking soil samples with a core sampler (Figure 4). Photo: Åsa Ståhl. Seeds with the capacity to accumulate heavy metals in the soil were selected (Figure 5). Photo: Louize Mazet.

The project brought together design researchers, environmental scientists and people from the community. Together, they discussed the past and present of the environment polluted by the glass industry. In addition, thoughts on a speculative future where plants could remediate the soil were exchanged. There is no easy fix for issues of soil contamination. Instead, the soil scanning workshops and invitation to plant seeds opened up different ways of sensitizing ourselves to soil communities in the area. They provided the conditions for sharing and articulating situated responses on how to go on living with it.

\section{The case of Murano: From waste to landscape}

The location of the second case also included a central area of glass production. Traces from the Anthropocene: Working with Soil was an artistic research project in the area of craft which took place in Venice, Italy, in the context of the Research Pavilion in 2019 (Elo et al., 2020). The objective of the study was to discuss the entwining of human and soil ontologies. In the project, craft practitioners used methods of soil contamination research together with their skill and knowledge in the area of ceramic art to investigate anthropogenic contamination in the Venice Lagoon area.

The craft practitioners familiarised themselves with the environmental research of the Venetian Lagoon. They proceeded by taking soil and sediment samples with the support of soil contamination specialists from the Finnish Environment Institute SYKE. After the samples were analysed for their heavy metals, the soils were regarded as materials for artistic production: the contaminated soil samples were processed into a fine slip and used as ceramic paints on large vessel forms built from clay from the local fields of Veneto. Through the research, the craft practitioners reflected on how matter changes into material (Adamson, 2018, pp. 151-156; Ingold, 2012, pp. 17-31), and what implications this process has on the environment.

One of the sites where the craft practitioners took soil samples was Murano, where glass making has been practised for nearly 700 years. The Muranese wasteland island of Sacca San Mattia offered a disturbing place to reflect on soil relations (see also Latva-Somppi \& Mäkelä, 2020, pp. 38-40). In places, there were blankets of glass shards partly covered by soil and grass. The broken pieces represented the production of skillfully made artefacts, but also the possible presence of, for example, copper, cobalt, cadmium, selenium and chromium in soil (Figure 6). The island was inhabited by rabbits and seagulls guarding their nests. When the craft practitioners returned once again later in the summer the same year, swarms of cicadas had emerged from underground and tall Aaron's Rods (Verbascum thapsus) rose persistently everywhere from the bare, glass-covered soil.

The heavy-metal analysis revealed an uncontestable connection to the metals used in the glass industry (see also Latva-Somppi et al., 2020, pp. 11-14). In several places, arsenic, silver and lead were detected. According to the senior research scientist of soil contamination Jussi Reinikainen (personal 
communication April 15, 2019) from the Finnish Environment Institute SYKE, the levels were not extremely alarming for humans, yet even at lower levels accumulation of certain metals present consequences to other living organisms. Heightened levels of these metals have been detected in clams and mussels in the waters near Murano (Giusti \& Zhang, 2002). Later, the craft practitioners learned that the island had been artificially built from glass waste, domestic waste and construction rubble and then completed with dredged sediments from the waterways and canals in the lagoon. This followed a long tradition of island-making in the Lagoon area (personal communication, anonymous local glass professional, ${ }^{2}$ February 11, 2019). It exemplified the amount of waste the glass industry produces, albeit in combination with solid waste from households and construction.

The ongoing research was exhibited in the Research Pavilion with an array of soil samples, maps and related research diaries. The display formed a material narrative, enabling an exchange of stories and thoughts around the contamination of the local environment to be shared with the audiences (Figure 7). The vessel forms were made using the ancient method of coiling and cited the forms of historic pottery, hence attaching the practice closely to the history of crafting objects (Latva-Somppi et al., 2020, pp. 7, 14-15) (Figure 8).

The public was invited to work with local brick clay alongside the craft practitioners, allowing a contemplative space to engage physically with clay in the given context (Figure 9). When working, the audience often shared their personal stories related to soil. In this way, the Research Pavilion acted as a platform for the vivid discussion around manifold meanings related to soil that was shared with craft practitioners and visitors - many of them being local residents of the Veneto area. In addition, the pavilion also hosted a public discussion with a soil contamination specialist.
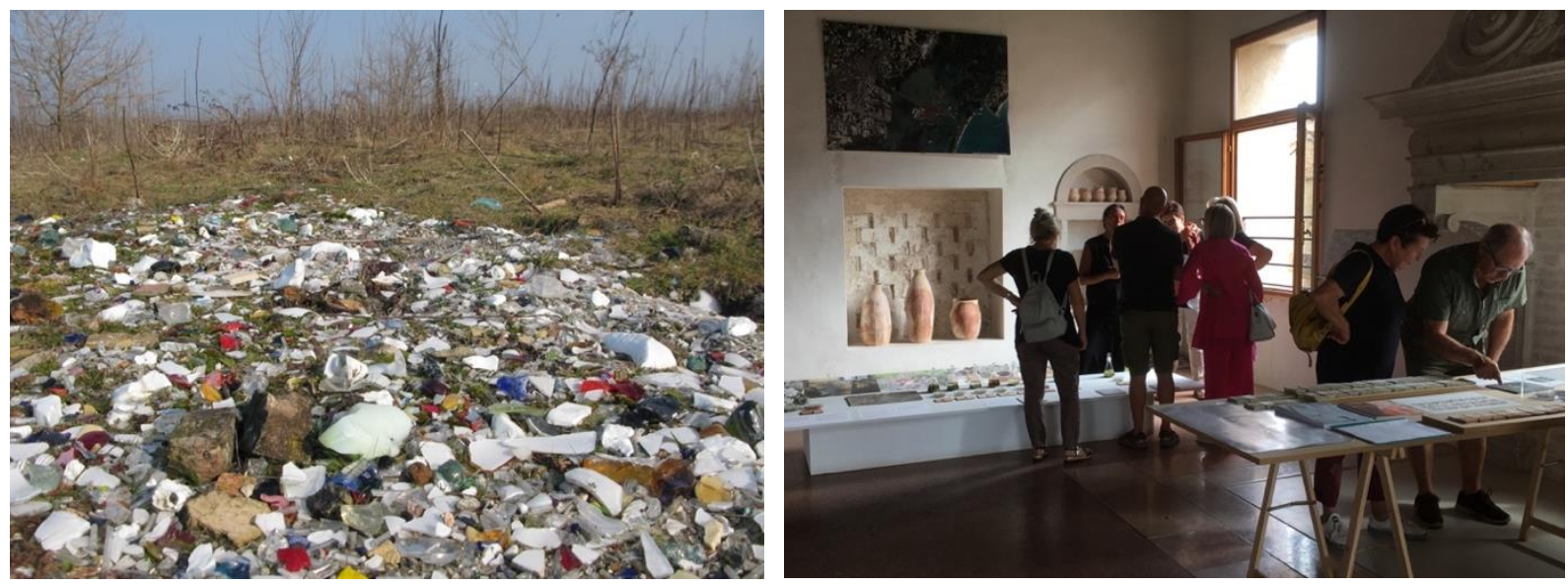

FIGURE 6 AND 7. The ground of Sacca San Mattia was partly covered with waste glass. Photo: Riikka Latva-Somppi (Figure 6). Engaging the audience in discussion. Photo: Maarit Mäkelä (Figure 7). 

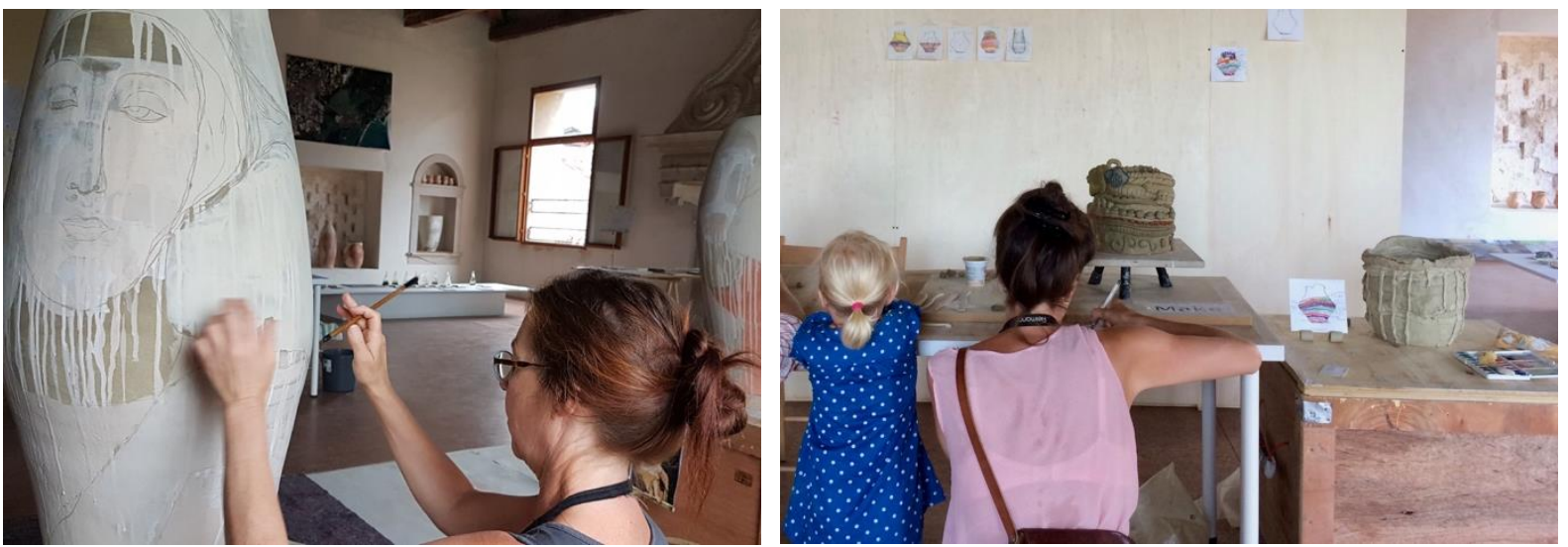

FIGURE 8 AND 9. The vessels were painted with contaminated soil. Photo: Riikka Latva-Somppi (Figure 8). Visitors worked with local brick clay. Photo: Tzuyu Chen (figure 9).

Using the geological research methods took the craft practitioners to the sites where they gathered the materials for their practice. The chosen methods also brought them to share their research ideas, enquiries and practices with various professionals of other fields. For example, soil contamination specialists shared their knowledge in several meetings and phone calls. They directed the craft practitioners to contact local environment officials. While only one of these contacts led to a meeting (see also Latva-Somppi \& Mäkelä, 2020, p. 37-38; Latva-Somppi et al., 2020, pp. 9-10), the researchers then used their own networks to proceed with the project. This unplanned trajectory led to encounters where the concern and need to care for soil was shared with local designers, glass and ceramic specialists and artist-activists. As the researchers were also educators, they returned to the sites in question with university students (Figure 10).

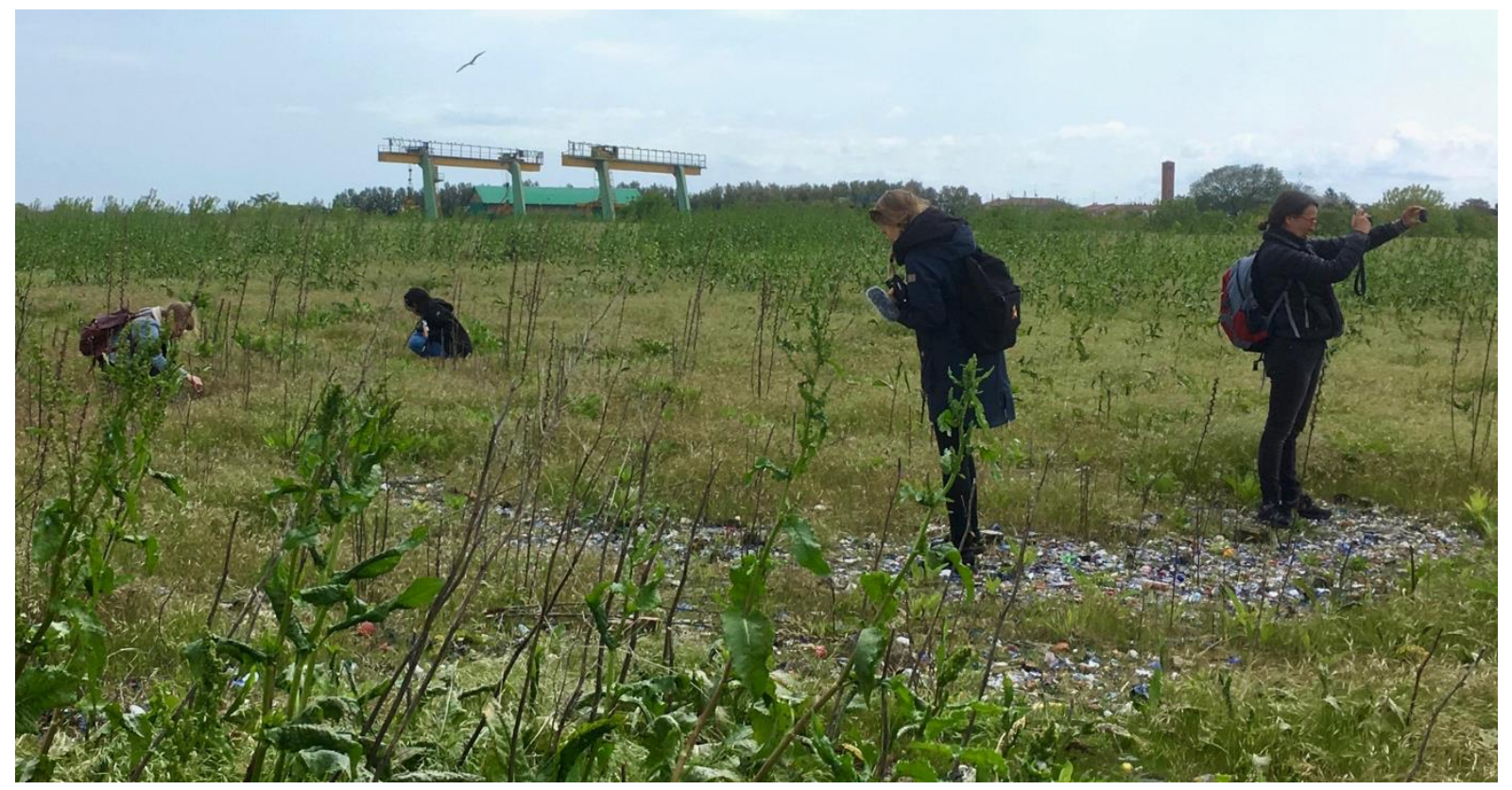

FIGURE 10. Getting to know the Muranese island together with students. Photo: Maarit Mäkelä.

\section{The case of Nuutajärvi: Ongoing speculations}

The third case is located in the Glass Village of Nuutajärvi in Urjala, Finland. In early 2020, the curators of the Soil Matters exhibition (www.designmuseum.fi/en/soil-matters), who are also the first and second authors of this paper, invited the Un/Making Studio to participate in the exhibition, which would 
gather together multiple soil-related design projects at the Design Museum in Helsinki. As all travel was restricted because of the pandemic COVID-19, the Finnish craft practitioners were invited, in a relaymanner, to implement the Un/Making Soil Communities project in the local glass scene in Finland. Soil Laboratory (www.soil-laboratory.aalto.fi), which was organised as a living laboratory and studio space at the exhibition, was used for analysing the soil and carrying the phytoremediation experiments. Participatory design, which previously took place in the form of workshops with the residents in the Kingdom of Crystal, was now reconstructed. Instead of that, a collaboration between a team of designresearchers from different backgrounds was shared with the public through the exhibition.

The Finnish research team consisted of a local glass professional with twenty years of professional and educational experience in glass blowing; the first author of this paper, Riikka LatvaSomppi, who has similarly worked as an artist and educator in the glass field for three decades; and a recently graduated designer, who had also participated in the case of Murano as a research assistant. Thus, the research team had a solid understanding of glass as a working medium. This knowledge included glass chemistry as well as the history of glass design and production in Finland.

Nuutajärvi Glass Village is the oldest site of the glass industry in Finland where glass making still continues. The factory there functioned from 1793 to 2014 in three different locations, and now Nuutajärvi is a village of glass artisans (Salo, 2015, p. 11-12). Unlike the cases of the Kingdom of Crystal and Murano, environmental research on the area concerning pollution from the glass industry was not publicly available. The samples were taken from sites that were found relying on old maps, stories told by the villagers and retired glassblowers, as well as observations of possible dumpsites (Figure 11).

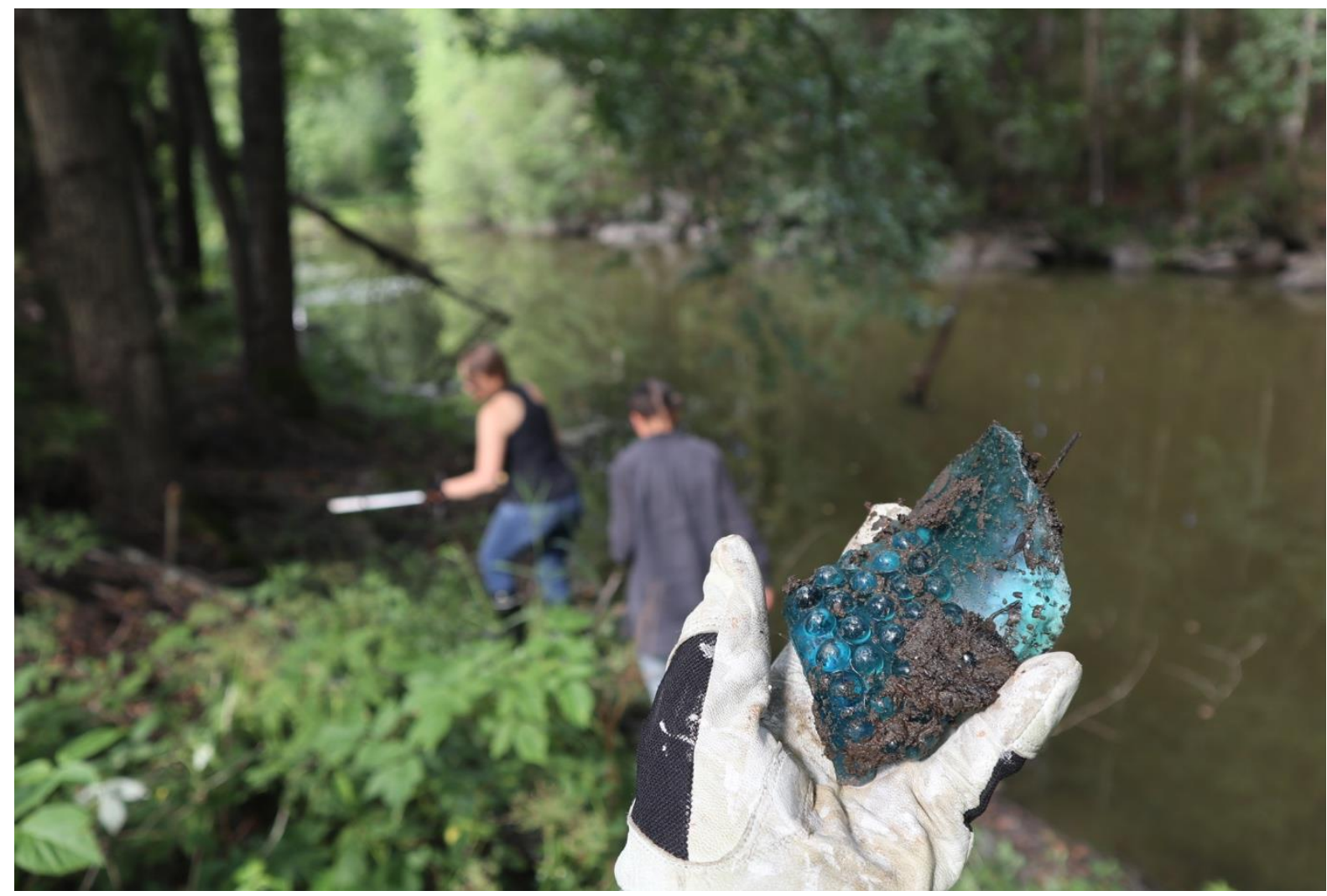

FIGURE 11. One of the sites where glass waste was known to be found was the riverbank. Photo: Tzuyu Chen.

Following the process of Un/Making Soil Communities in the Kingdom of Crystal, the metal content of the soil samples was analysed. The soil scanning events took place in the exhibition space, and the public was invited to follow the event (Figure 12). Three samples which showed a varying presence of heavy metals were selected for the phytoremediation experiment. For example, a sample taken from by the most recent glass factory had 5.3 times the higher guideline value set for assessing ecological and health 
risks (Ministry of the Environment, Finland, 2007) of chromium in soil and twice the higher guideline value of antimony. Respectively, the sample taken from a riverbank was high in zinc, chromium, arsenic and lead. The third sample, taken from a roadside where the glass industry's waste formed the foundation for the road, also revealed arsenic and lead levels that exceeded the higher guideline values set in the Finnish legislation for soil contamination.

Currently, when writing this paper, the seeds sent by our Swedish colleagues are sprouting from the soil in the exhibition space (Figure 13). We plan to care for them for two months before harvesting. The plants will then be dried and analysed to reveal whether they have drawn heavy metals from the soil. We then plan to use our ceramic knowledge to develop them into ceramic ash glazes relying on traditional glazing recipes. The process is open to the public in the exhibition space in the form of a research display, including the phytoremediation experiment, talks and other events such as soil scanning. The audiences can also follow the daily care of the plants. This mode of making the caring for soil visible can be regarded as a way of making it political (Mazé, 2013, p. 89).
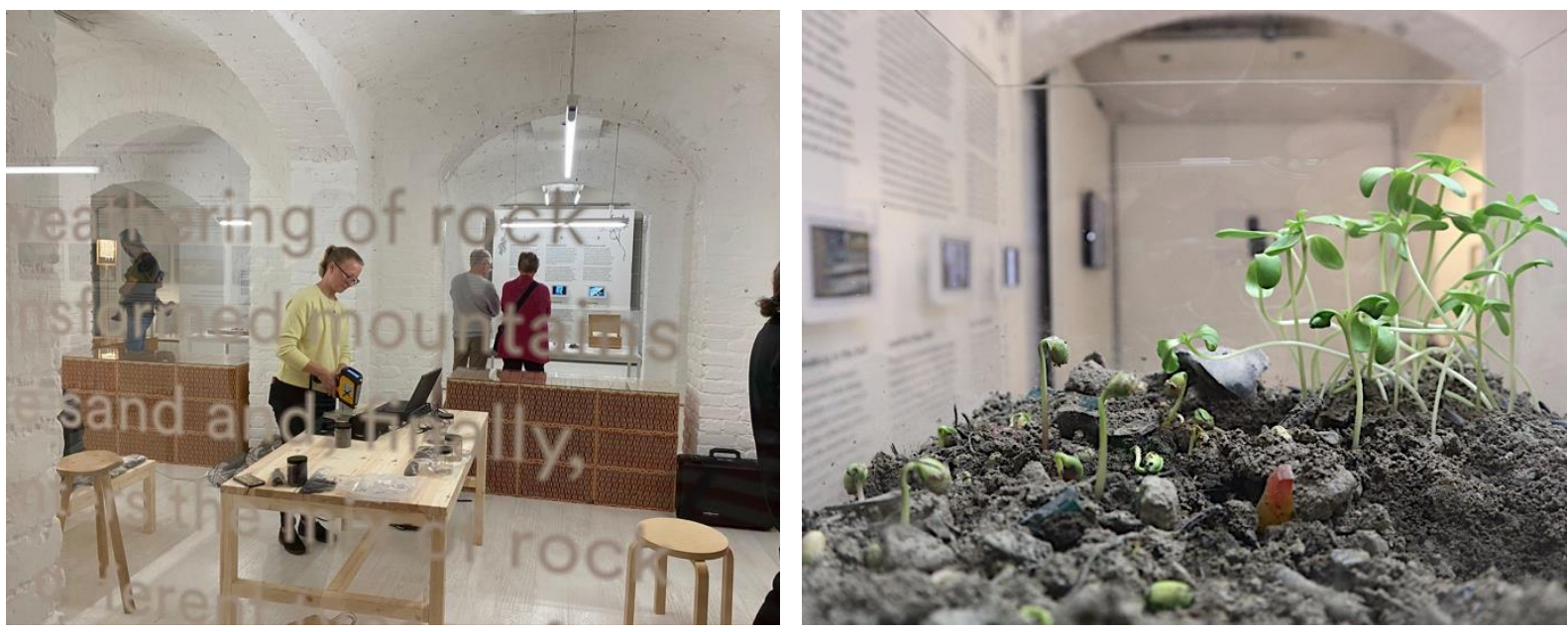

FIGURE 12 AND 13. Nuutajärvi soils were scanned for their heavy metals in the exhibition space. Photo: Minni Soverila / Design Museum Helsinki (Figure 12). Sunflowers and soybeans sprouting from the roadside soil of Nuutajärvi. Photo: Tzuyu Chen (Figure 13).

\section{UNDERSTANDING OUR ROLES AS CITIZENS OF SOIL COMMUNITIES}

Reflecting on the different sites of glass production, we have understood that the soil contamination that follows is very similar regardless of the local, possibly varying, practices and environmental legislation. The materials and processes used in the glass industry follow the historical narrative of innovations and regulations - and aesthetic preferences. Our analyses were in line with the environmental research of the areas: the most prominent metals found around glass industries are lead, arsenic, and zinc, but sometimes even cadmium exceeds the guideline values. It has been shown, for example, that a low pH-level considerably increases the risk of hazardous concentrations of harmful metals, such as lead and arsenic, escaping into the environment (Mutafela et al., 2019). In many places, the soil is not only polluted by toxic metals, or littered by glass trash, but also the landscape itself may be an artificial construct. Waste glass has transformed large areas of land, creating landfills as in the Kingdom of Crystal, foundations for roads as in Nuutajärvi and even islands, as in Murano.

During the projects, we also learned that plants may have capacities to act on their own in phytoremediation. One of the soil samples from Nuutajärvi was taken by the Prykäri building, where exceptionally high willowherbs (Chamaenerion angustifolium) grew (Figure 14). Prykäri used to be a storage house for potash, a potassium-rich ingredient in glass, which was formerly made by extraction from wood and plant ashes. The sample from the topsoil revealed a high level of cadmium. We hypothesised that this might have resulted from willowherb's capacity to accumulate cadmium (Trubina \& Vorobeichik, 2013) from the soil that has been enriched with cadmium from the wood ash (Ministry 
of Agriculture and Forestry, 2001). However, we were not able to prove this with the explorative scanning of the plant fibres. Also, Aaron's rods, which had taken over the Muranese island, are known to accumulate heavy metals, especially lead (Čudić \& Stojiljković, 2016) (Figure 15). Nevertheless, we regard this - the appearance of specific plants in certain polluted areas - as an interesting finding that should gain more attention in our future studies.

Being a part of a specific community does not automatically create a need to care for it. Working in the context of the polluted soil in the three different locations of the former glass industry has allowed us the space and time to reflect on our roles in the soil community. Our roles are those of citizens of the community but also members who are consumers and designers and makers. Although we do not live in the areas of our case studies, we share a feeling of belonging to these sites, partly through our responsibility as design-researchers and professionals of the craft and design field. A sense of belonging cultivates the need to care. We are also aware of our accountability as educators of future generations of designers and craft persons, and feel the need to pass on a solid understanding of their share in world-making (see Saito, 2017, p. 141; also in Latva-Somppi et al. 2020).
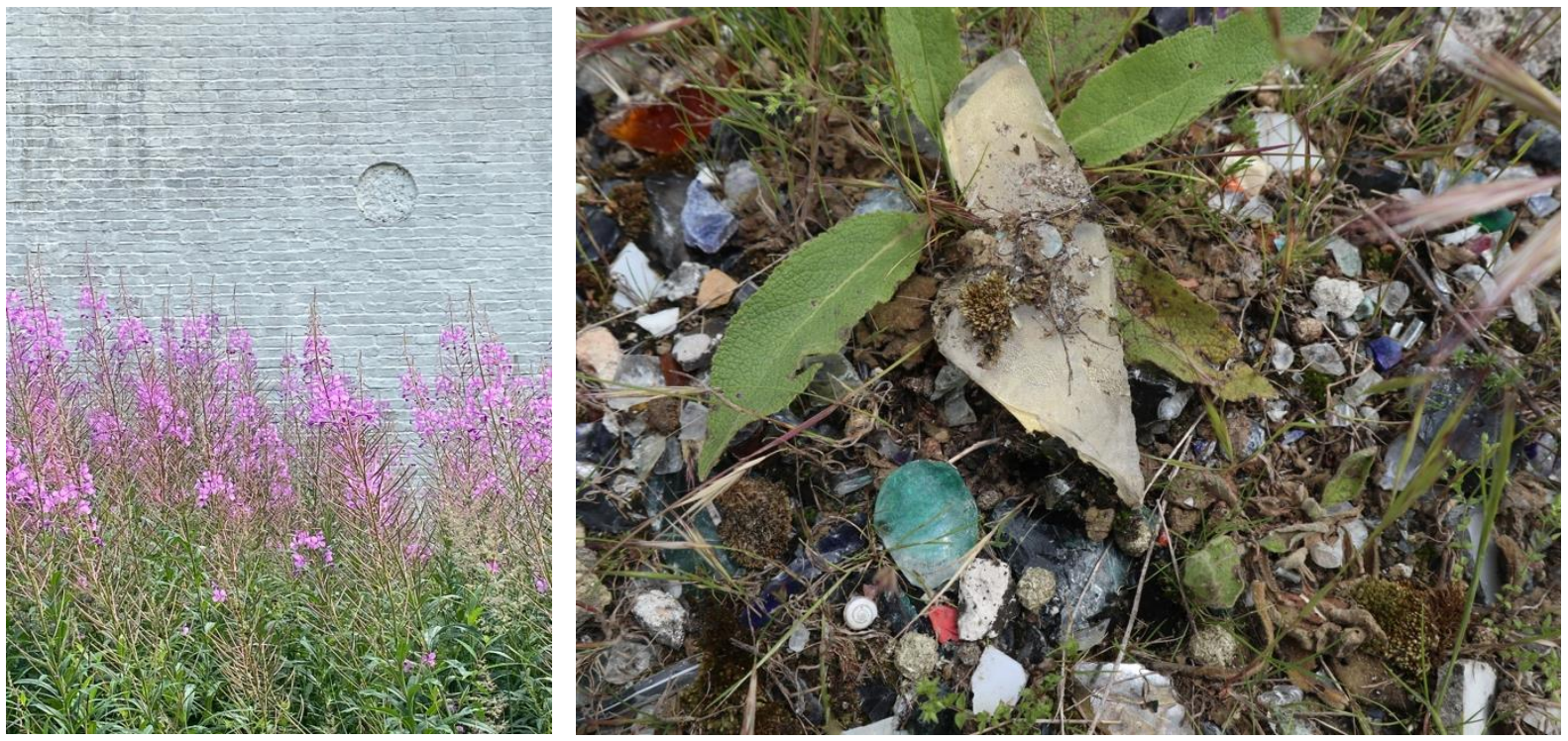

FIGURE 14 AND 15. Willowherb growing by the Prykäri-building. Photo: Sara Hulkkonen (Figure 14). Aaron's rods pushing from the ground in Sacca San Mattia, Murano. Photo: Riikka Latva-Somppi (Figure 15).

\section{CONCLUSION}

Through this paper, we have considered, (1) how does craft and design practice, both the history and the present, affect the soil at sites of glass production? and (2) how may we as design and craft practitioners act with responsibility and care for them? Building on the fundamental ideas of craft and design, we have discussed three ways with which to engage in the time-requiring, slow, messy and sometimes political tasks of care (Puig de la Bellacasa, 2015, pp. 15-17) concerning the consequences of the craft and design industry. These three ways are: First, going to the sites in question and exploring them through the skills and knowledge acquired through our practice; second, inviting others, such as locals, authorities, scientists, colleagues, students and exhibition visitors to engage in dialogue; third, making the processes, reflections and outcomes visible in the forms of exhibitions, events, discussions and lectures.

In questioning how our practices, presented in this paper, are situated in the craft and design field, we rely on the designerly knowledge of processes and materials. As craft and design practitioners and also as makers, our practice is deeply rooted in the materiality of soil. We are thus entangled in the consequences of the making of our field of practice. More so, we are engaged in the present. Through these cases, we have explored ways of acting, with hope, in the intersection of the natural and artificial 
world. We have not only focused on the known troubles of polluted soil as a consequence of design, but we have also opened up trouble in a place where it was not previously on the public agenda by literally digging up soil, revealing its contaminants and bringing it into an exhibition setting. By bringing these cases together in this paper and through relaying invitations across sites and different design practices, we not only show how issues of soil matter across locations, but also that they make connections across craft and design practices.

\section{ACKNOWLEDGEMENTS}

Kristina Lindström and Åsa Ståhl thank Louize Mazet, Alicia Smedberg, Laura Ferrans and Sina Shahabi Ghahfarokhi, Ragnhild Lekberg, Ida Bencke and Växjö Art Gallery, and finally the Swedish Research Council grant 2017-02198 for funding of the Un/making Soil Communities in the Kingdom of Crystal.

Riikka Latva-Somppi and Maarit Mäkelä thank Tzuyu Chen, Sara Hulkkonen and Hannu Revitzer, Maarit Saresma from the Geological Survey of Finland, the Finnish Environment Institute SYKE and Design Museum Helsinki, and finally the Jenny and Antti Wihuri Foundation for funding Riikka Latva-Somppi's doctoral research. 


\section{REFERENCES}

Adamson, G. (2018). Fewer, Better Things: The Hidden Wisdom of Objects. Bloomsbury.

Akama, Y., Light, A. \& Kamihira, T. (2020). Expanding Participation to Design with More-Than-Human Concerns. Proceedings of the Participatory Design Conference, Manizales, Colombia, 16(1). https://doi.org/10.1145/3385010.3385016

Akama, Y., Pink, S. \& Sumartojo, S. (2018). Uncertainty and Possibility. New Approaches to Future Making in Design Anthropology. Bloomsbury Publishing Plc.

Čudić, V. \& Stojiljković, D. (2016). Phytoremediation potential of wild plants growing on soil contaminated with heavy metals. Archives of Industrial Hygiene and Toxicology 67(3), 229-239. https://doi.org/10.1515/aiht-2016-67-2829

Denizen, S. (2013). Three Holes: In the Geological Present. In E. Turpin (Ed.). Architecture in the Anthropocene: Encounters Among Design, Deep Time, Science and Philosophy. Open Humanities Press. https://dx.doi.org/10.3998/ohp.12527215.0001.001

Elo, M., Heikkinen, T., \& Slager, H. (2020). Ecologies of Practice. RUUKKU - Studies in Artistic Research 14. http://ruukku-journal.fi/fi/issues/14/editorial

Fletcher, K., St. Pierre, L. \& Tham, M. (2019). Introduction. In K. Fletcher, L. St. Pierre, M. Tham (Eds.), Design and Nature: A Partnership (pp. 92-108). Routledge. https://doi.org/10.4324/9781351111515-14

Giusti, L. \& Zhang, H. (2002). Heavy metals and arsenic in sediments, mussels and marine water from Murano (Venice, Italy). Environmental Geochemistry and Health 24(1), 47-65. https://doi.org/10.1023/A:1013945117549

Haraway, D. (1991). Simians, Cyborgs and Women. The Reinvention of Nature. Routledge.

Haraway, D. (2016). Staying with the Trouble. Making Kin in the Chthulucene. Duke University Press.

Helmfrid, A. (2014). Konceptuell modell över spridningsvägar för glasbruksföroreningar i Rejmyre samhälle (Publication n:o 384) [Bachelor thesis, University of Lund]. https://lup.lub.lu.se/studentpapers/search/publication/4460023

Hogland, W., Burlakovs, J., Mutafela, R. \& Jani, Y. (2019). From glass dump to phytoremediation park. IOP Conference Series Earth and Environmental Science 390:012007. https://doi.org/10.1088/17551315/390/1/012007

Ingold, T. (2012). Toward an Ecology of Materials. Annual Review of Anthropology, 41, 427-442. http://www.jstor.org/stable/23270720

Kallipoliti, L. (2018). History of Ecological Design. Oxford Research Encyclopedia of Environmental Science. https://doi.org/10.1093/acrefore/9780199389414.013.144

Latva-Somppi, R. \& Mäkelä, M. (2020) Exploring Ecological and Material Sensitivity through Craft Practice in the Context of the Venice Lagoon. Aisthesis 13(1), 31-46. https://doi.org/10.13128/Aisthesis-10916

Latva-Somppi, R., Mäkelä, M. \& Gündeşlioğlu, Ö. (2020). Traces from the Anthropocene: Working with Soil. RUUKKU - Studies in Artistic Research, 14. https://doi.org/10.22501/ruu.697190

Leopold, A. (with Kingsolver, B.). (2020). A Sand County Almanac and Sketches Here and There. Oxford University Press. (Original work published 1949)

Lindström, K. \& Ståhl, Å. (2020). Un/Making in the Aftermath of Design. Proceedings of the Participatory Design Conference, Manizales, Colombia, 16(1) https://doi.org/10.1145/3385010.3385012

Lindström, K. \& Ståhl, Å. (2019). Caring design experiments in the aftermath. Proceedings of the Nordic Design Research Society Conference, Espoo, Finland. 8. 1-9. https://archive.nordes.org/index.php/n13/article/view/495/465

Malm, A. \& Hornborg, A. (2014). The geology of mankind? A critique of the Anthropocene narrative. The Anthropocene Review, 1(1), 62-69. https://doi.org/10.1177/2053019613516291 
Mazé, R. (2013). Who is sustainable? Querying the politics of sustainable design practices. In R. Mazé, L. Olausson, M. Plöjel, J. Redström \& C. Zetterlund (Eds.), Critical perspectives and dialogues about design and sustainability (pp. 83-121). Axl Books.

Metsänkylä, A. \& Suutari, P. (1992). Työryhmä: Verstaikko. Raportti lasinpuhalluksesta Nuutajärvellä. National Board of Antiquities.

Ministry of Agriculture and Forestry (2001). Cadmium in Wood Ash Used as Fertilizer in Forestry: Risks to the Environment and Human Health. https://julkaisut.valtioneuvosto.fi/bitstream/handle/10024/80715/2001_5\%20Cadmium\%20in\%20Woo d\%20Ash\%20Used\%20as\%20Fertilizer\%20in\%20Forestry.pdf

Ministry of the Environment, Finland (2007). Government Decree on the Assessment of Soil Contamination and Remediation Needs 214/2007, March 1. www.finlex.fi/fi/laki/kaannokset/2007/en20070214.pdf

Mutafela, R., Marques, M., Jani, Y., Kriipsalu, M. \& Hogland, W. (2019). Physico-chemical characteristics of fine fraction materials from an old crystal glass dumpsite in Sweden. Chemistry and Ecology. 35(9), 877-890, https://doi.org/10.1080/02757540.2019.1648442

Puig de la Bellacasa, M. (2015). Making Time for Soil: Technoscientific futurity and the pace of care. Social Studies of Science, 45 (5), 691-716. https://doi.org/10.1177/0306312715599851

Saito, Y. (2017). Aesthetics of the Familiar: Everyday Life and World-Making. Oxford University Press. https://doi.org/10.1093/oso/9780199672103.001.0001

Salo, M-L. (2015). Into ja polte. Nuutajärven lasikylän tarinoita. Muotohuone Oy.

Simon, H.A. (1969). The sciences of the artificial. MIT Press.

St. Pierre, L. (2019). Design and Nature: A History. In K. Fletcher, L. St. Pierre, \& M. Tham (Eds.), Design and Nature: A Partnership (pp. 92-108). Routledge.

Steffen, W., Crutzen, P.J. \& McNeill, J.R. (2007). The Anthropocene: Are Humans Now Overwhelming the Great Forces of Nature, AMBIO: A Journal of the Human Environment, 36(8), 614-621, https://doi.org/10.1579/0044-7447(2007)36[614:TAAHNO]2.0.CO;2

Strathern, M. (2004). Partial Connections. Rowman and Littlefield. (Original work published 1991)

Trubina, M.R. \& Vorobeichik, E.L. (2013). Content of heavy metals in medicinal plants in the area under aerotechnogeneous impact of the Middle Urals copper smelter. Rasitel'nye Resursy 49(2), 203-222. https://www.cabdirect.org/globalhealth/abstract/20133318877

Uddh-Söderberg, T.E., Gunnarsson, S.J., Hogmalm, K.J., Boel, M.I., Lindegård \& G., Augustsson, A.L.M. (2015). An assessment of health risks associated with arsenic exposure via consumption of homegrown vegetables near contaminated glassworks sites. Sci Total Environ, 536, 189-197. https://doi.org/10.1016/j.scitotenv.2015.07.018

\footnotetext{
${ }^{1}$ Participatory design and speculative design both aim to engage and involve various stakeholders in issues related to design. They do, however, differ in their approaches. While participatory design aims to involve those who are affected by a new design in the design process, speculative design often exhibits evocative design objects with the aim of sparking debate and imagination.

${ }^{2}$ During our fieldwork, we interviewed two experienced glass professionals from Murano about the contamination in the lagoon area. They wished to remain anonymous as they felt that the topic was delicate.
} 